\title{
Temu Baur Budaya dan Matematika : Kue Tradisional Konjo pada Pengenalan Bentuk Geometri Anak Usia Dini
}

\author{
Khaerun Nisa $^{\otimes_{1}}$, Syarifah Halifah ${ }^{2}$ \\ Balai Penelitian dan Pengembangan Agama Makassar, Kementerian Agama Republik \\ Indonesia( ${ }^{(1)}$ \\ Pendidikan Islam Anak Usia Dini, Institut Agama Islam Negeri Parepare, Indonesia(2) \\ DOI: $10.31004 /$ obsesi.v6i1.936
}

\begin{abstract}
Abstrak
Kesenjangan antara matematika di sekolah dengan realitas matematika dalam kehidupan serta minimnya lembaga PAUD/PIAUD yang menerapkan pemanfaatan kearifan lokal pada proses pembelajaran menjadi latar belakang penelitian ini urgen dilakukan. Penelitian ini bertujuan mendeskripsikan konsep geometri pada kue tradisional Konjo serta proses penggunaan kue tradisional Konjo pada pengenalan geometri anak usia dini. Penelitian ini merupakan penelitian kualitatif dengan pendekatan etnografi. Data penelitian dikumpulkan melalui observasi, wawancara dan dokumentasi. Hasil penelitian menunjukkan bahwa terdapat sembilan jenis kue Konjo tradisional yang mengandung konsep geometri, yaitu dumpi eja dan dumpi paripuluk lekleng yang mengandung konsep lingkaran, kalimbu' dan tetuk mengandung konsep persegi panjang, ruhu'-ruhu' memuat konsep kerucut. Onde-onde dan kacipo' memuat konsep bola, gogoso bittahe berisi konsep balok dan roko'-roko' cangkudi' memuat konsep limas segiempat. Proses pemanfaatan kue Konjo tradisional dalam pengenalan bentuk geometri pada anak usia dini meliputi kegiatan pembuka, kegiatan inti, dan kegiatan penutup.
\end{abstract}

Kata Kunci: kue tradisional konjo; geometri; anak usia dini

\begin{abstract}
The gap between mathematics in schools and the reality of mathematics in life and the lack of PAUD/PIAUD institutions that apply the use of local wisdom in the learning process is the background of this research is urgent to do. The purpose of this research is to describe the concept of geometric in traditional Konjo cake and the process of applying the use of traditional Konjo cake in the introduction of geometry for early childhood. This research is a qualitative research with ethnographic approach. Research data is collected through observations, interviews and documentation. The results showed that there are nine types of traditional Konjo cake containing geometric concepts, namely dumpi eja and dumpi paripuluk lekleng containing the concept of circles, kalimbu' and tetuk containing rectangular concepts, ruhu'-ruhu' contains the concept of cones. Onde-onde and kacipo' contains the concept of balls, gogoso bittahe contains the concept of beams and roko'-roko' cangkudi' contains the concept of rectangular limas. The process of using traditional Konjo cake in the introduction of geometric shapes in early childhood includes opening activities, core activities, and closing activities.
\end{abstract}

Keywords: konjo's traditional cake; geometry; early childhood.

Copyright (c) 2020 Khaerun Nisa, Syarifah Halifah

$\triangle$ Corresponding author :

Email Address : kn.khaerunnisa@gmail.com (Mutiara Indah Village NN-21 Gowa, Sulawesi Selatan)

Received 30 November 2021, Accepted 10 Januari 2021, Published 2 June 2021 


\section{PENDAHULUAN}

Matematika dan budaya merupakan dua hal yang sering diterjemahkan sebagai sesuatu yang terpisah, bahkan tidak memiliki keterikatan. Timbulnya perspektif tersebut tidak terlepas dari terjadinya kesenjangan antara sajian matematika pada bangku sekolah dengan realitas matematika dalam kehidupan sehari-hari (Pathuddin dan Raehana, 2019). Secara empiris, pertemuan bahkan pembauran antara matematika dan budaya dalam keseharian adalah sesuatu yang tidak terhindarkan. Sebab budaya merupakan unit lengkap dan inklusif yang digunakan dalam masyarakat, sedangkan kehadiran matematika dalam kehidupan manusia digunakan untuk memecahkan berbagai permasalahan sehari-hari (Hardiarti, 2017).

Tahun 1977 seorang matematikawan bernama Brazil D'Ambrosio memperkenalkan suatu istilah yang diyakini dapat menjadi jembatan antara matematika dan budaya, yang hari ini dikenal dengan etnomatematika (Wahyuni dkk., 2013). Selanjutnya, D'Ambrosio yang menyatakan bahwa menciptakan jembatan antara budaya dan matematika merupakan sebuah upaya mengidentifikasi pola berpikir yang mampu menimbulkan kemunculan beragam bentuk matematika, yang kemudian dinamai etnomatematika (D'Ambrosio, 1985). Sehingga merujuk pada istilah tersebut, maka dapat diterjemahkan bahwa beragam konsep matematika dapat dieksplorasi dalam budaya. Selain itu, semakin menegaskan bahwa matematika dan budaya memiliki pertautan, serta dapat digunakan sebagai rujukan belajar matematika yang konkret. Secara terminologi, etnomatematika didefinisikan selaku matematika yang dimanifestasikan oleh kelompok budaya seperti masyarakat, suku, kelompok buruh, anakanak dari kelompok usia tertentu dan kelas profesional.

Etnomatematika telah menjangkau banyak sektor. Geometri termasuk salah satu bidang kajian etnomatematika yang banyak dieksplor oleh beberapa peneliti. Geometri adalah salah satu bidang kajian matematika yang dapat dinyatakan paling konkrit yang berkaitan dengan realitas kehidupan. Dan seyogyanya dapat membantu anak dalam belajar, sehingga anak dapat menghubungkan dan mengimplementasikan teori geometri ke dalam kehidupan sehari-hari (Choi \& Park, 2013).

Beberapa penelitian terdahulu terkait geometri dalam kajian etnomatematika adalah eksplorasi etnomatematika rumah gadang Minangkabau Sumatera Barat (Rahmawati Z dan Muchlian, 2019), pembelajaran matematika berbasis etnomatematika melalui permainan tradisional engklek (Maulida dan Jatmiko, 2019), etnomatematika: eksplorasi geometri dalam topeng Malangan (Alimatun, 2019), etnomatematika; pembuatan kerajinan tangan anyaman bambu masyarakat Osing di Desa Gintangan Banyuwangi sebagai bahan ajar geometri (Fajar dkk., 2018), etnomatematika Melayu: pertautan antara matematika dan budaya pada masyarakat Melayu Riau (Hasanuddin, 2017), eksplorasi etnomatematika pada batik Madura (Zayyadi, 2017), etnomatematika kesenian rebana sebagai sumber belajar matematika (Putri, 2017), dan eksplorasi etnomatematika masyarakat Sidoarjo oleh (Rachmawati, 2012).

Adapun implementasi geometri lainnya dalam kajian etnomatematika dapat ditemui dalam kehidupan masyarakat Konjo, yaitu pada kue tradisional khas suku Konjo. Suku Konjo adalah salah satu etnis yang memiliki posisi unik di Sulawesi Selatan, yang mana berdasarkan persebarannya terdapat pada pegunungan dan pesisir. Masyarakat Konjo pesisir adalah masyarakat yang bermukim pada Kabupaten Bulukumba bagian Timur, yaitu pada Kecamatan Bonto Bahari, Kecamatan Bonto Tiro, Kecamatan Herlang dan Kecamatan Kajang. Adapun masyarakat Konjo pegunungan meliputi Desa Parigi ke timur Kabupaten Gowa, setelah barat Sinjai, bagian timur dan timur laut Kabupaten Maros (sekitar Camba), perbatasan selatan Kabupaten Bone, dan daerah pengunungan utara Kabupaten Bantaeng (Nisa', 2019). Namun dalam penelitian ini, berfokus pada suku Konjo pesisir yang berdiam di Kabupaten Bulukumba bagian Timur, yaitu Kecamatan Herlang. Suku Konjo di Kecamatan Herlang merupakan salah satu suku yang masih ketat menjaga tradisi dan budayanya, termasuk dalam hal kue tradisional. Secara fisik, kue tradisional Konjo mengandung konsep geometri. 
Mengingat pentingnya matematika dalam kehidupan, sehingga pengetahuan matematika ini menjadi sesuatu yang mutlat untuk diketahui dan dikuasai pada semua level usia. Pengenalan matematika kepada anak sejak usia dini, dapat membantu anak memiliki life skills di masa depan. Masa kanak-kanak adalah masa keemasan, dimana pertumbuhan dan perkembangan anak pesat. Sehingga anak yang berada pada rentang usia tersebut, diupayakan untuk mengeksplor berbagai hal positif serta mendapatkan pengetahuan dan pembelajaran sejak dini (Padila dkk, 2019). Demikian halnya dengan pengenalan matematika sejak usia dini, merujuk pada hasil Program Penilaian Siswa Internasional (PISA) tahun 2015 yang mengekspos jika Indonesia berkinerja buruk dan menduduki urutan 65 dari 75 negara yang ikut serta untuk matematika (Wahyuda dkk, 2019). Sehingga pengalaman awal pada anak usia dini dapat menjadi bekal pada kesuksesan matematika anak di masa depan (Winitri, dkk, 2020).

Hal ini sejalan dengan kompetensi dasar (KD) kurikulum 2013 paud usia 5-6 tahun yang dibagi menjadi empat kelompok adalah kompetensi dasar sikap spiritual, sosial, pengetahuan dan keterampilan. Pada kompetensi dasar pengetahuan, memuat kriteria pengembangan kognitif, berpikir logis, simbolik, dan pemecahan masalah. Kriteria-kriteria tersebut merupakan konsep pengenalan logika matematis yang salah satunya mengenai pengenalan benda-benda disekitarnya dengan muatan pembelajaran pengenalan bentuk lingkaran, segitiga, segiempat, balok, limas, kerucut, bola dan seterusnya. Selain itu, dalam permendikbud nomor 146 tahun 2013 mengenai kurikulum 2013 paud yang merujuk pada dokumen KTSP yang terdiri dari dokumen I dan dokumen II. Dimana pada dokumen I menjabarkan muatan pembelajaran yang terintegrasi dengan nilai kearifan lokal.

Pengintegrasian pembelajaran dengan kearifan lokal kemudian menjadi sesuatu yang penting untuk dilakukan. Khususnya pada pengenalan bentuk-bentuk geometri pada anak usia dini. Selain itu, berdasarkan hasil observasi yang dilakukan oleh peneliti pada Raudhatul Atfhal di Kabupaten Bulukumba bagian Timur, diperoleh bahwa guru dalam melakukan pengenalan bentuk-bentuk geometri kepada anak, umumnya menggunakan media pembelajaran yang telah tersedia di Raudhatul Atfhal ; permainan balok, puzzle, ilustrasi gambar ataupun menyanyi dengan gerakan. Permainan balok digunakan oleh guru untuk mengenalkan balok. Pengenalan bentuk geometri menggunakan ilustrasi gambar, biasanya digunakan untuk mengenalkan segitiga, persegi, persegi panjang, limas dan kerucut. Selain itu, guru juga melakukan pengenalan bentuk geometri berupa lagu yang disertai dengan gerakan, misalnya dalam mengenalkan lingkaran. Adapun lagu yang dimaksud adalah lingkaran kecil, lingkaran besar serta lagu topi saya bundar.

Mengacu kepada dokumen I yang termuat dalam permendikbud nomor 146 mengenai pembelajaran yang terintegrasi dengan nilai kearifan lokal dan fenomena hasil observasi yang diperoleh peneliti mengenai minimnya lembaga pendidikan PAUD/PIAUD yang memanfaatkan dan mengenalkan pembelajaran berbasis kearifan lokal pada anak usia dini dipandang sebagai sesuatu yang penting, maka adapun tujuan dari penelitian ini adalah untuk mendeskripsikan konsep matematika yang termuat pada kue tradisional Konjo dan proses penerapan penggunaan kue tradisional Konjo pada pengenalan geometri pada anak usia dini. Pengintegrasian pembelajaran dalam hal ini pengenalan geometri berbasis kearifan lokal pada anak usia dini, diharapkan dapat menjadi upaya penciptaan suasana belajar dan perancangan pengalaman belajar yang mengintegrasikan budaya lokal sebagai bagian dari proses pembelajaran.

\section{METODOLOGI}

Penelitian dilaksanakan di Kabupaten Bulukumba bagian timur, dimana masyarakat suku Konjo Pesisir mayoritas bermukim. Penelitian ini menggunakan metode deskriptif kualitatif dengan pendekatan etnografi. Peneliti bertindak sebagai human instrument, dimana peneliti berkaitan langsung dengan penelitian. Peneliti tumbuh dan besar dalam lingkungan suku Konjo. Selain itu peneliti juga berperan sebagai pengumpul data dalam penelitian yang 
perannya tidak dapat digantikan. Data dalam penelitian ini diperoleh melalui observasi, wawancara dan dokumentasi. Observasi dilakukan pada salah satu pasar tradisional suku Konjo yaitu pasar Tanuntung yang mana banyak penjual yang menjajalkan kue tradisional Konjo. Meskipun terdapat juga kue tradisional Konjo yang tidak dapat ditemui di pasar tradisional, seperti dumpi eja yang hanya dapat ditemui pada acara pernikahan. Pada kegiatan observasi, peneliti melakukan pengamatan langsung terhadap bentuk beberapa varian kue tradisional suku Konjo yang dianggap memuat konsep geometri. Selanjutnya peneliti melakukan wawancara dengan lima orang penjual kue tradisional untuk memperoleh beberapa informasi terkait bahan dan cara membuat kue tersebut. Langkah selanjutnya, peneliti melakukan perekaman etnografi, yaitu melakukan pengambilan gambar terhadap beberapa varian kue tradisional Konjo yang diasumsikan memuat konsep geometri. Setelah mengumpulkan data, peneliti melakukan analisis data, klasifikasi data dan pengambilan kesimpulan. Analisis data dilakukan terhadap data lapangan yang telah dikumpulkan, dalam hal ini beberapa varian kue tradisional Konjo terkait bentuk fisik yang diduga memuat konsep geometri. Selanjutnya peneliti melakukan klasifikasi terhadap beberapa varian kue tradisional Konjo tersebut ke dalam dua kategori yaitu bangun datar dan bangun ruang serta melakukan penjabaran terkait sifat-sifat geometri yang termuat dalam kue tradisional tersebut. Peneliti melakukan penarikan kesimpulan yang diuraikan berupa deskripsi terkait terjadinya pembauran kue tradisional Konjo dengan konsep geometri. Kemudian peneliti menguraikan proses pemanfaatan kue tradisional Konjo yang memuat konsep geometri pada pengenalan geometri untuk anak usia dini. Sedangkan implikasi dari pemanfaatan kue tradisional Konjo pada kemampuan anak usia dini mengenal geometri belum dibahas di dalam penelitian ini. Alur penelitian dapat dilihat pada bagan 1.

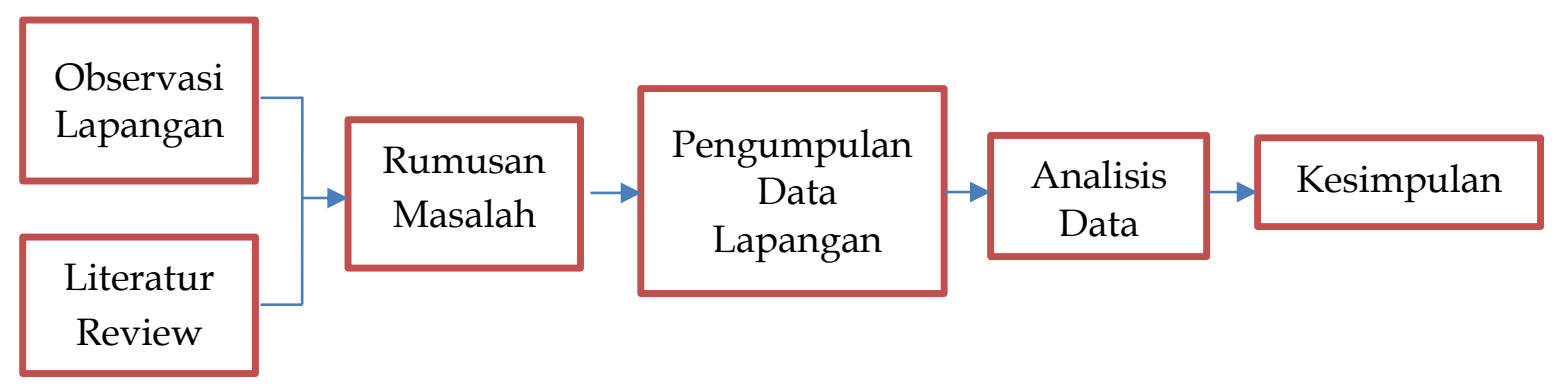

Bagan 1. Alur Penelitian

\section{HASIL DAN PEMBAHASAN}

\section{Kue Tradisional Konjo dalam Kajian Geometri}

Sesuai dengan hasil observasi, dokumentasi dan pengumpulan data yang dilakukan oleh peneliti, terdapat sembilan jenis kue tradisional Konjo yang memuat konsep geometri. Kue tradisonal yang dimaksud adalah dumpi eja (kue merah), dumpi paripulu' lekleng (kue ketan hitam), kalimbu', tetuk, ruhu'-ruhu', onde-onde, kacipo', gogoso bittahe dan roko'-roko' cangkudi'. Berdasarkan hasil temuan dan analisis terhadap bentuk-bentuk kue tradisional tersebut, maka kue tradisional Konjo dapat diklasifikasikan dalam bentuk geometri bangun datar dan bangun ruang. Kue tradisional Konjo dalam konsep geometri bangun datar dapat ditemukan pada dumpi eja (kue merah), dumpi paripulu' lekleng (kue ketan hitam), kalimbu' dan tetuk. Sedangkan kue tradisional Konjo dalam konsep geometri bangun ruang dapat ditemukan pada ruhu'-ruhu', onde-onde, kacipo', gogoso bittahe dan roko'-roko' cangkudi'.

\section{Dumpi Eja (Kue Merah)}

Dumpi eja atau disebut kue merah. Dumpi eja adalah salah satu kue tradisional suku Konjo yang umumnya terdapat pada baku'puli. Baku' puli adalah seserahan yang dibawa oleh mempelai laki-laki kepada pihak mempelai perempuan. Seserahan tersebut dijadikan sebagai 

DOI: 10.31004/obsesi.v6i1.936

buah tangan untuk keluarga calon mempelai perempuan bahwa anaknya telah melangsungkan pernikahan. Dumpi eja disebut kue merah karena warnanya yang kemerahmerahan. Dumpi eja terbuat dari tepung beras pulut yang dicampur dengan gula merah, lalu digoreng di atas minyak panas dan dibentuk menyerupai lingkaran.

\section{Dumpi Paripulu' Lekleng}

Dumpi paripulu' lekleng atau juga disebut kue ketan hitam. Kue ini sesuai dengan namanya terbuat dari tepung ketan hitam, dicampur gula pasir, santan, telur, minyak dan pada permukaannya ditaburi wijen. Kue ini dapat dikukus maupun dipanggang dan umumnya didapati pada acara pernikahan, akikah, dan syukuran rumah baru.
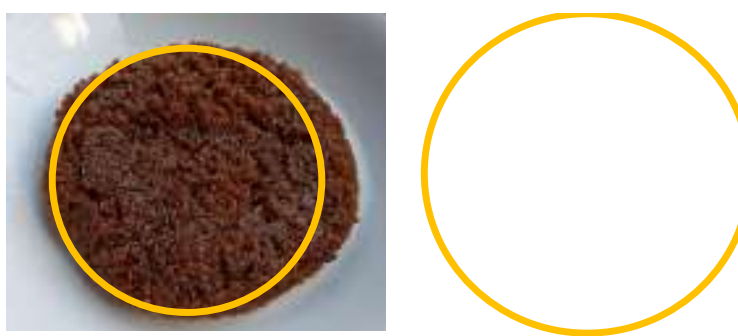

Gambar 1. Konsep geometri pada dumpi eja
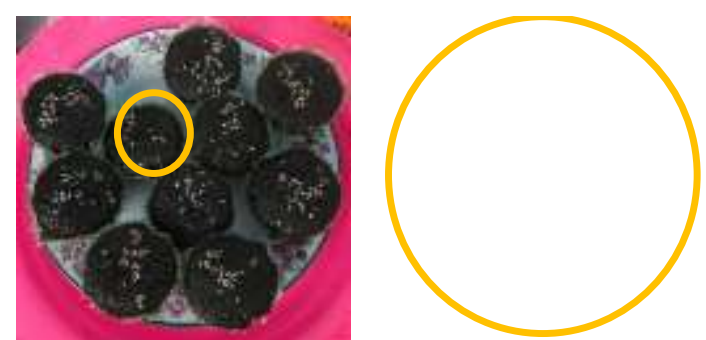

Gambar 2. Konsep geometri pada dumpi paripulu' lekleng

Berdasarkan hasil analisis pada Gambar 1 dan Gambar 2, diperoleh bahwa pada kue tradisional Konjo dumpi eja dan dumpi paripulu' lekleng mengandung konsep geometri yaitu lingkaran. Berikut sifat lingkaran sesuai dengan Gambar 1 dan Gambar 2, yaitu memiliki titik pusat, jarak titik pusat ke titik manapun pada lingkaran selalu sama, hanya memiliki satu sisi, tidak memiliki sudut, serta memiliki simetri lipat dan putar yang tidak terbatas jumlahnya.

\section{Kalimbu'}

Kalimbu' adalah salah satu jenis kue tradisional Konjo yang terbuat dari pisang yang dibaluti singkong rebus dan kelapa muda parut.
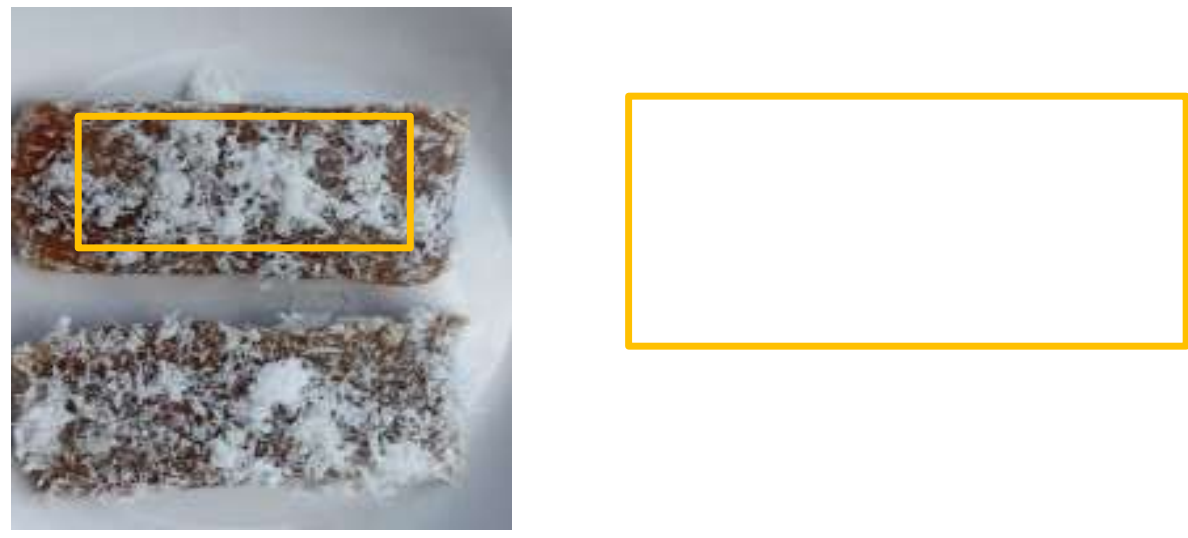

Gambar 3. Konsep geometri pada kalimbu'

\section{Tetuk}

Tetuk merupakan salah satu kue tradisional suku Konjo yang banyak dijumpai ketika bulan ramadhan sebagai takjil dan pada acara mappaccing (malam pacar) pernikahan suku Konjo. Kue ini terbuat dari tepung terigu, tepung beras, santan, garam, gula merah dan gula pasir. Secara fisik, kue ini berbentuk seperti perahu, yang mana setiap sisinya berbalut daun pandan. 

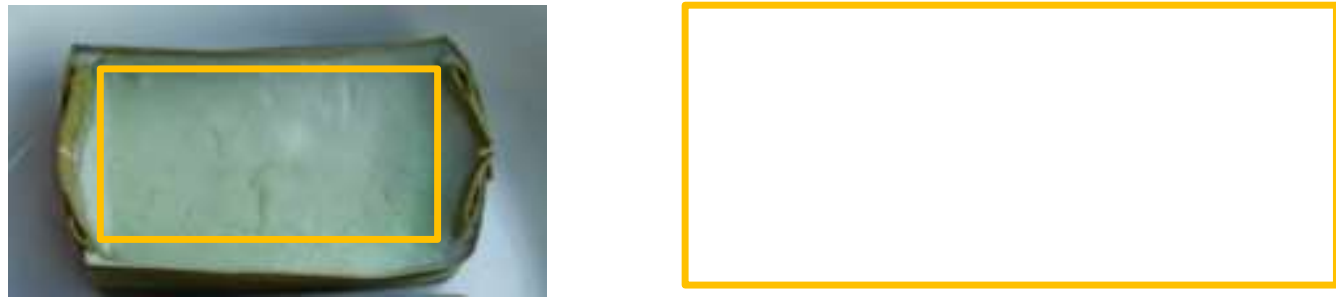

Gambar 4. Konsep geometri pada tetuk

Berdasarkan hasil analisis pada Gambar 3 dan Gambar 4, diperoleh bahwa pada kue tradisional Konjo kalimbu' dan tetuk mengandung konsep geometri yaitu persegi panjang. Adapun sifat persegi panjang sesuai dengan Gambar 3 dan Gambar 4, yaitu memiliki empat sisi, dimana sisi-sisi yang berhadapan sama panjang dan sejajar, memiliki 4 titik sudut, dimana semua sudutnya sama besar yaitu sudut siku-siku 90 derajat, memiliki 2 simetri lipat, memiliki 2 simetri putar, serta kedua diagonalnya berpotongan dan membagi dua sama panjang.

\section{Ruhu'-ruhu'}

Ruhu'-ruhu' merupakan kue tradisional khas suku Konjo yang berbahan dasar beras ketan dan gula merah. Adonan tersebut kemudian digoreng pada wajan besar. Dalam proses penggorengan sangat menentukan keberhasilan membentuk kue ini menyerupai kerucut.
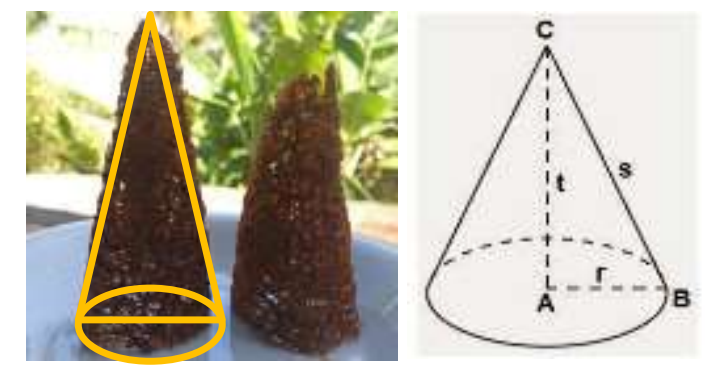

Gambar 5. Konsep geometri pada ruhu'-ruhu'

Berdasarkan hasil analisis pada Gambar 5, diperoleh bahwa pada kue tradisional Konjo ruhu'-ruhu' mengandung konsep geometri yaitu kerucut. Adapun sifat-sifat kerucut sesuai dengan Gambar 5, yaitu mempunyai dua buah permukaan, yaitu alas yang berbentuk lingkaran dan selimut kerucut, tidak memiliki sudut, dan memiliki satu titik puncak.

\section{Onde-onde}

Onde-onde merupakan salah satu jajanan populer yang ada di Indonesia. Meskipun demikian, setiap daerah memiliki ciri khas dalam membuat onde-onde, termasuk suku Konjo. Suku Konjo dalam membuat onde-onde menggunakan bahan dasar beras ketan hitam, gula merah, kelapa parut dan wijen. Gula merah dan kelapa parut digunakan sebagai isian ondeonde.
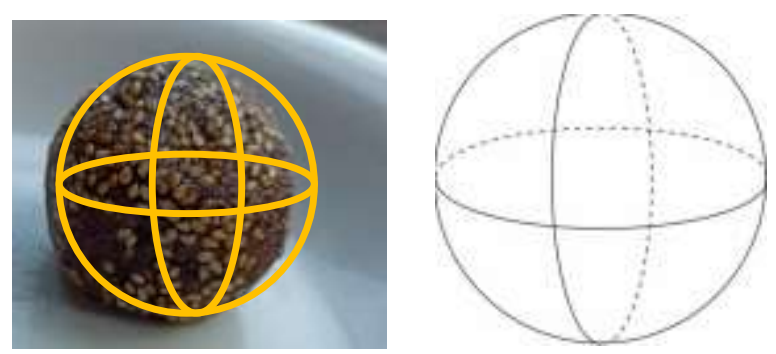

Gambar 6. Konsep geometri pada onde-onde 


\section{Kacipo'}

Kacipo' merupakan salah satu kue tradisional Konjo yang secara fisik menyerupai onde-onde. Kacipo' memiliki tekstur yang lebih kecil, keras dan tidak memiliki isian. Kue ini juga tidak sepopuler dan mudah dijumpai di pasar-pasar tradisional seperti onde-onde. Kacipo' umumnya dijadikan sebagai camilan. Kue ini berbahan dasar beras ketan hitam, gula pasir dan wijen.
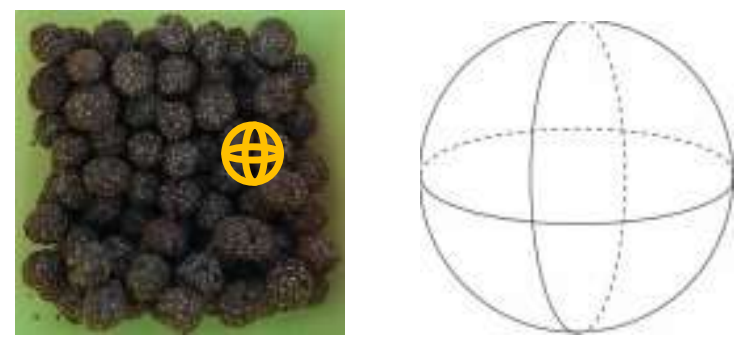

\section{Gambar 7. Konsep geometri pada kacipo'}

Berdasarkan hasil analisis pada Gambar 6 dan Gambar 7, diperoleh bahwa pada kue tradisional Konjo onde-onde dan kacipo' mengandung konsep geometri yaitu bola. Berikut sifat-sifat bola sesuai dengan Gambar 6 dan Gambar 7, yaitu mempunyai satu sisi, sisi lengkung tertutup, tidak mempunyai titik sudut dan tidak mempunyai bidang datar.

\section{Gogoso Bittahe}

Gogoso Bittahe adalah kue tradisional Konjo yang berbahan dasar singkong yang dicampur dengan gula merah, pada bagian tengah kue ini berisi kelapa parut yang juga dicampur dengan gula merah. Kue ini dibalut menggunakan daun pisang, yang mana pada kedua sisinya dieratkan menggunakan lidi, kemudian dikukus. Secara fisik, kue gogoso bittahe mengandung konsep geometri bangun ruang, yaitu balok.

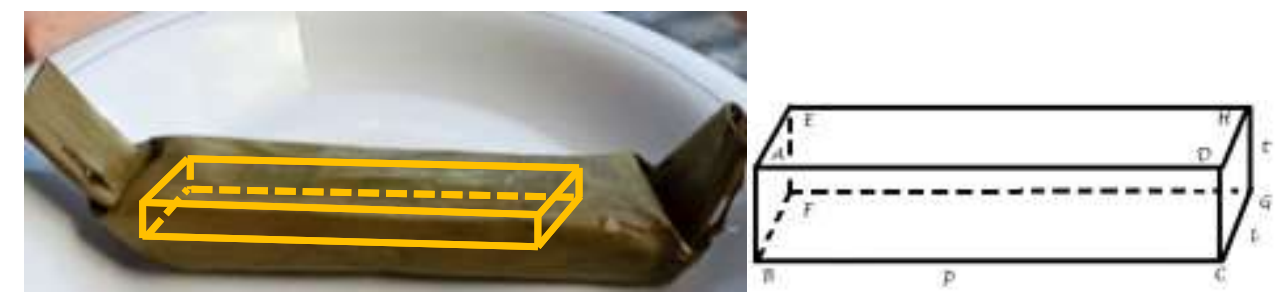

Gambar 8. Bentuk geometri pada gogoso bittahe

Berdasarkan hasil analisis pada Gambar 8, diperoleh bahwa pada kue tradisional Konjo gogoso bittahe mengandung konsep geometri yaitu balok. Berikut sifat-sifat balok sesuai dengan Gambar 8, yaitu mempunyai sisi-sisi yang berbentuk persegi panjang, rusukrusuk yang sejajar memiliki ukuran yang sama panjang, setiap diagonal ruang pada sisi yang berhadapan memiliki ukuran sama panjang serta setiap bidang diagonal pada balok memiliki bentuk persegi panjang.

\section{Roko'-roko' cangkudi'}

Roko'-roko' cangkudi' adalah kue tradisional Konjo yang dibuat dari beras ketan yang dihaluskan, gula merah dan kelapa parut sebagai isiannya. Kue ini mudah dijumpai pada pasar tradisional. 

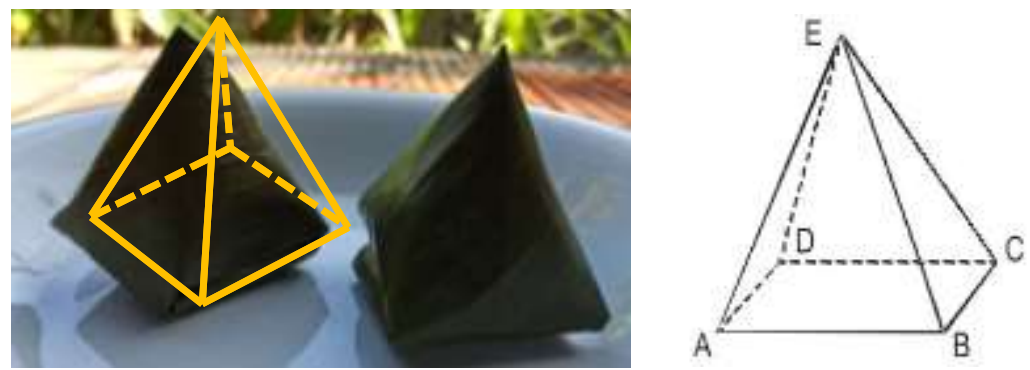

Gambar 9. Konsep geometri pada roko'-roko' cangkudi'

Berdasarkan hasil analisis pada Gambar 9, diperoleh bahwa pada kue tradisional Konjo roko'-roko' cangkudi' mengandung konsep geometri yaitu limas segiempat. Berikut sifat-sifat limas segiempat sesuai dengan Gambar 9, yaitu memiliki alas yang berbentuk segiempat, memiliki lima titik sudut yang terdiri dari empat sudut dan satu sudut berada di puncak serta mempunyai lima sisi, empat sisi berbentuk segitiga dan satu sisi segiempat.

\section{Kue Tradisional Konjo sebagai Media Pengenalan Geometri pada Anak Usia Dini}

Fase anak berusia 5-6 tahun merupakan fase yang sangat tepat untuk mengenalkan geometri pada anak. Sebab pada fase ini, anak sangat peka terhadap rangsangan dan memiliki rasa keingintahuan yang tinggi. Sehingga ketika anak menerima ransangan baru, maka anak akan merespon dengan baik dan sangat cepat. Beberapa peneliti telah melakukan kajian mengenai pengenalan geometri pada anak usia dini dengan beragam media pembelajaran yang ditawarkan. Beberapa penelitian terdahulu mengenai media yang digunakan dalam mengenalkan geometri pada anak usia dini ; pengenalan bentuk geometri melalui metode bermain tradisional sondah (Nurjani dan Jubaedah, 2020), penerapan permainan pindah kamar dalam menumbuh kembangkan kemampuan mengenal bentuk geometri pada anak usia dini (Sumartini, 2018), kemampuan mengenal bentuk geometri melalui permainan balok anak usia dini (Dewi, 2019), peningkatan kemampuan kognitif anak melalui permainan ludo geometri di Paud Habibul Ummi II (Jawati, 2013), serta peningkatan kecerdasan visual spasial anak usia dini melalui permainan Maze (Rosidah, 2014).

Berdasarkan hasil kajian dari penelitian ini, maka kue tradisional Konjo juga pula dimanfaatkan sebagai media dalam mengenalkan geometri kepada anak usia dini. Pada sub bab sebelumnya telah diuraikan mengenai beberapa jenis kue tradisional Konjo yang memuat konsep geometri. Dumpi eja dan kue paripulu' lekleng yang mengandung konsep lingkaran, kalimbu' dan tetuk mengandung konsep persegi panjang, ruhu'-ruhu' mengandung konsep kerucut, kacipo' dan onde-onde mengandung konsep bola, gogoso bittahe mengandung konsep bola, serta roko'-roko' cangkudi' yang mengandung konsep segiempat. Beragam kue tradisional Konjo ini dapat difungsikan sebagai media pembelajaran dalam mengenalkan geometri pada anak usia dini.

Media yang digunakan dalam pengenalan geometri pada anak usia dini yang digunakan berasal dari benda konkrit, yaitu kue tradisional Konjo yang kemudian diabstraksi dalam konsep-konsep geometri. Kegiatan pembelajaran pengenalan geometri pada anak usia dini menggunakan kue tradisional Konjo dalam implementasinya dapat melalui rancangan pembelajaran berupa RPPM dan RPPH yang terintegrasi dengan tema pembelajaran PAUD. Adapun sub temanya, dapat dikreasikan oleh guru dengan mengacu pada Permendikbud nomor 147 mengenai kurikulum PAUD.

Pengenalan geometri pada anak usia dini dengan media pembelajaran berbasis kue tradisional Konjo ini dapat menggunakan pendekatan Montessori. Pendekatan montessori merupakan pendekatan pembelajaran yang diajukan oleh Maria Montessori, dimana konsep tersebut memuat mengenai peran guru yang divergen terhadap konsep peran guru konservatif. Montessori mengubah peran guru yang sebelumnya memposisikan guru sebagai pusat pembelajaran, menjadi guru yang mampu mengarahkan anak dalam mengembangkan 
diri, mampu mengobservasi, responsif akan kesiapan anak, serta mampu menyiapkan lingkungan yang memadai, mampu menjalin kerjasama dengan anak (Cipta, 2018).

Adapun tahap-tahap metode pembelajaran berbasis pendekatan Montessori, yaitu tahap menunjukkan, mengenal dan mengingat. Berikut peneliti akan menguraikan tahapan pengenalan geometri pada anak usia dini dengan memanfaatkan kue tradisional Konjo sebagai media pembelajarannya. Hal ini diharapkan dapat menjadi referensi bagi para guru anak usia dini khususnya di Bulukumba bagian Timur. Dimana tahapan kegiatan tersebut meliputi kegiatan pembuka, kegiatan inti dan kegiatan kegiatan penutup, dengan menggunakan pendekatan Montessori.

Proses pelaksanaan pemanfaatan media kue tradisional Konjo dalam pengenalan bentuk geometri terdiri dari kegiatan pembuka, kegiatan inti, dan kegiatan penutup.

\section{Kegiatan Pembuka}

Kegiatan pembuka dapat dilakukan seperti yang umumnya dilakukan oleh para guru pendidikan anak usia dini, yaitu merujuk pada indikator NAM (Nilai Agama Moral). Kegiatan pembuka umumnya dilakukan dengan berdoa agar kegiatan pembelajaran berjalan lancar, serta sebagai wadah bagi guru untuk menanamkan nilai-nilai agama. Selanjutnya kegiatan pembuka dapat dilanjutkan dengan bernyanyi. Dalam rangka pengenalan geometri kepada anak usia dini, kegiatan bernyanyi dapat dilakukan dengan menggunakan lagu yang mengandung konsep-konsep geometri seperti lagu lingkaran kecil lingkaran besar, topi saya bundar dan seterusnya yang disertai dengan gerakan. Melalui kegiatan bernyanyi yang memuat konsep-konsep geometri dapat menjadi ajang pengenalan beberapa bentuk geometri pada anak, selain itu kegiatan ini juga dapat merangsang psikomotorik.

Setelah guru melakukan pengenalan awal mengenai bentuk geometri dengan bernyanyi, selanjutnya guru dapat menunjukkan benda konkrit yang akan dijadikan sebagai media untuk mengenalkan geometri pada anak usia dini dengan menggunakan metode demonstrasi. Dimana benda yang akan dijadikan sebagai media untuk mengenalkan geometri pada anak usia dini dalam penelitian ini adalah kue tradisional Konjo yang terdiri dari sembilan jenis yang meliputi dumpi eja, dumpi paripulu' lekleng, kalimbu', tetuk, ruh'-ruhu', onde-onde, kacipo, gogoso bittahe, dan roko'-roko' cangkudi'. Sembilan jenis kue tradisional Konjo ini, tidak diperkenalkan kepada anak dalam satu pertemuan. Namun dapat dibagi menjadi dua pertemuan berdasarkan identifikasi konsep geometri yang termuat pada sembilan jenis kue tradisional Konjo, yang terbagi menjadi bangun datar dan bangun ruang. Guru dapat memulai pada pengenalan geometri kepada anak menggunakan kue tradisional Konjo yang mengandung konsep geometri bangun datar dan selanjutnya pada pertemuan berikutnya menggunakan kue tradisional Konjo yang mengandung konsep geometri bangun ruang.

Guru dapat mengenalkan bentuk-bentuk geometri kepada anak dengan terlebih dahulu menyebutkan nama-nama dari varian kue tradisional tersebut, kemudian menunjukkan satu persatu beserta dengan sifat-sifatnya dengan metode yang menyenangkan. Misalnya, setelah guru menyebutkan nama dari salah satu kue tersebut, guru dapat menanyakan kepada anak bahwa apakah ada anak yang pernah mendengar nama dari kue tersebut, pernah memakannya, mengetahui rasanya, dan mengetahui bentuknya. Setelah guru mengajukan pertanyaan-pertanyaan tersebut kepada anak, ketika ada anak yang memberikan feedback, maka guru dapat memberikan kesempatan kepada beberapa anak untuk menyampaikan pengalamannya mengenai kue tradisional tersebut di depan kelas. Akan tetapi sebaliknya, jika anak masih asing dengan kue tradisional tersebut, maka selanjutnya guru dapat menunjukkan kue tersebut, lalu memberikan beberapa penjelasan atau demonstrasi secara singkat dan dengan bahasa yang mudah dipahami oleh anak, khususnya mengenai bentuk dari kue tradisional tersebut yang mengandung konsep geometri. Selanjutnya, sebagai persiapan untuk memasuki kegiatan inti, guru dapat membagi kelompok untuk penugasan. 


\section{Kegiatan Inti}

Dalam pelaksanaan kegiatan inti, guru terlebih dahulu melakukan pembagian kelompok. Jumlah kelompok dapat menyesuaikan jumlah anak pada TK atau Raudhatul Athfal. Pada bagian ini, peneliti mencoba memberikan ilustrasi dengan melakukan pembagian kelompok sebanyak tiga kelompok. Dimana terdiri dari kelompok A, B, dan C. Kelompok A, diberi tugas untuk menceritakan mengenai beberapa jenis kue tradisional Konjo terkait rasa, warna, tekstur dan khususnya pada bentuknya dan lokasi dimana anak menjumpai kue tersebut (jika pernah melihatnya sebelumnya). Misal dumpi eja yang merupakan kue tradisional Konjo yang hanya dapat ditemukan di Bulukumba Timur pada saat melaksanakan pernikahan. Berbentuknya bulat seperti lingkaran dan berwarna merah.

Selanjutnya kelompok B, diberi tugas untuk mengenali beberapa bentuk kue tradisional dengan menggambar bentuk kue tradisional tersebut. Misal kue tetuk yang berbentuk persegi panjang. Guru dapat menyediakan kertas hvs sebanyak kue tradisional yang diberikan kepada anak. Selanjutnya anak dapat menaruh kue tetuk tersebut di atas kertas hvs, kemudian mengikuti setiap lekukan luar dari kue tetuk tersebut.

Kelompok $C$ dapat diberi tugas untuk mencocokkan gambar, dimana dalam hal ini guru perlu menyiapkan desain bentuk-bentuk geometri yang termuat pada kue-kue tradisional tersebut. Selanjutnya anak dapat mencocokkan jenis-jenis kue tradisional Konjo yang tepat untuk ditempatkan pada desain bentuk-bentuk geometri yang telah disiapkan oleh guru. Selain menggunakan cara tersebut dalam mencocokkan kue tradisional dengan bentukbentuk geometri yang telah disediakan oleh guru, dapat pula digunakan metode mencocokkan gambar dengan guru menyiapkan sebuah Lembar Kerja Anak (LKA). Dimana dalam LKA tersebut guru dapat membagi LKA menjadi dua bagian, pada bagian kiri guru dapat menginput gambar dari sembilan jenis kue tradisional Konjo tersebut, kemudian pada bagian kanan guru dapat menginput secara acak bentuk-bentuk geometri yang termuat pada kue tradisional Konjo. Selanjutnya siswa diberikan instruksi untuk mencocokan gambar kue tradisional Konjo pada bagian kanan LKA dengan bentuk-bentuk geometri yang termuat pada kue tradisional Konjo yang terdapat pada LKA bagian kanan.

\section{Kegiatan Penutup}

Kegiatan penutup dapat dijadikan guru untuk memberikan dukungan serta tanya jawab kepada siswa mengenai pengalaman belajar terhadap pengenalan geometri melalui kue tradisional Konjo. Guru dapat memberikan kesempatan kepada beberapa anak untuk berbagi pengalaman belajarnya, khususnya dalam pengenalan geometri melalui kue tradisional Konjo. Guru juga bertugas untuk memberi apresiasi terhadap hasil kerja siswa dalam bentuk bintang dan maupun komentar positif. Guru menyampaikan pesan-pesan pulang berdasarkan tema kegiatan, bahwa dalam bentuk-bentuk geometri bisa ditemui pada lingkungan sekitar, misalnya pada kue tradisional Konjo. Meskipun pengenalan bentuk geometri tidak hanya terbatas pada kue tradisional, namun dapat pula diindetifikasi melalui benda-benda yang berada disekitar. Hal tersebut sejalan dengan pembelajaran Montessori yang menyatakan bahwa pengalaman terhadap lingkungan nyata merupakan aspek penting.

\section{SIMPULAN}

Penggunaan media pembelajaran berbasis kearifan lokal berupa kue tradisional Konjo pada pengenalan geometri anak usia ini tidak hanya mengasah kognitif tetapi juga psikomotorik. Pengenalan matematika didapatkan darii bentuk-bentuk geometri sebaiknya tidak diberikan kepada anak sebagai produk jadi yang siap pakai, melainkan sebagai suatu bentuk kegiatan yang mengkronstruksi konsep matematika. Sehingga dikemudian hari matematika tidak menjadi momok yang menakutkan bagi anak. Melalui kehadiran pemanfaatan kearifan lokal dalam pembelajaran diharapkan anak dapat mengenal, mencintai, bangga, menjadikan inspirasi kearifan lokal daerahnya. 


\section{UCAPAN TERIMA KASIH}

Puji syukur kehadirat Allah SWT atas limpahan rahmat dan karunia-Nya serta ucapan terima kasih kepada segenap pihak yang telah berkontribusi sehingga peneliti mampu merampungkan penelitian dan menghadirkan tulisan ini di tengah-tengah pembaca yang budiman.

\section{DAFTAR PUSTAKA}

Alimatun Nisa Jurusan Pendidikan Matematika, R., \& UIN Maulana Malik Ibrahim Malang, P. (2019). Etnomatematika: Eksplorasi Geometri Dalam Topeng Malangan. Prosiding SI MaNIs (Seminar Nasional Integrasi Matematika Dan Nilai-Nilai Islami), 3(1), 2580460.

Choi, K. M., \& Park, H. J. (2013). A comparative analysis of geometry education on curriculum standards, textbook structure, and textbook items between the U.S. and Korea. Eurasia Journal of Mathematics, Science and Technology Education, 9(4), 379-391. https:// doi.org/10.12973/eurasia.2013.947a

Cipta, D. A. S. (2018). Penerapan Pendekatan Montessori untuk Menanamkan Pemahaman Konsep Bilangan Cacah pada Siswa TK Putera Zaman Malang. Matematika Dan Pembelajaran, 6(1), 30. https:// doi.org/10.33477/mp.v6i1.440

D'Ambrosio, U. (1985). Ethnomathematics and its Place in the History and Pedagogy of Mathematics. For the Learning of Mathematics, 5(1), 44-48.

Dewi, E. Y. P. (2019). Kemampuan Mengenal Bentuk Geometri Melalui Permainan Balok Anak Usia Dini. Journal on Early Childhood Education Research (JOECHER), 1(1), 32-45. https://doi.org/10.37985/joecher.v1i1.5

Fajar, F. A., Sunardi, \& Yudianto, E. (2018). Etnomatematika Pembuatan Kerajinan Tangan Anyaman Bambu Masyarakat Osing di Desa Gintangan Banyuwangi Sebagai Bahan Ajar Geometri. Kadikma, 9(3), 97-108.

Hardiarti, S. (2017). Etnomatematika: Aplikasi Bangun Datar Segiempat Pada Candi Muaro Jambi. Aksioma, 8(2), 99. https:// doi.org/10.26877/aks.v8i2.1707

Hasanuddin, H. (2017). Etnomatematika Melayu: Pertautan Antara Matematika dan Budaya pada Masyarakat Melayu Riau. Sosial Budaya, 14(2), 136. https://doi.org/10.24014/sb.v14i2.4429

Jawati, R. (2013). Peningkatan Kemampuan Kognitif Anak Melalui Permainan Ludo Geometri Di Paud Habibul Ummi Ii. Spektrum: Jurnal Pendidikan Luar Sekolah (PLS), 1(1), 250. https://doi.org/10.24036/spektrumpls.v1i1.1537

Maulida, S. H., \& Jatmiko. (2019). Pembelajaran Matematika Berbasis Etnomatematika Melalui Permainan Tradisional Engklek. Pembelajaran Matematika Berbasis Etnomatematika Melalui Permainan Tradisional Engklek, 5(01), 561-569.

Nisa', K. (2019). Parunrungi Baju and Attarasa's Tradition on Akil Balig Process of Konjo Community in Eastern Bulukumba. Al-Qalam, 25(2), 421. https://doi.org/10.31969/alq.v25i2.737

Padila, P., Andari, F. N., \& Andri, J. (2019). Hasil Skrining Perkembangan Anak Usia Toddler antara DDST dengan SDIDTK. Jurnal Keperawatan Silampari, 3(1), 244-256. https://doi.org/10.31539/jks.v3i1.809

Pathuddin, H., \& Raehana, S. (2019). Etnomatematika: Makanan Tradisional Bugis Sebagai Sumber Belajar Matematika. MaPan, 7(2), 307-327. https://doi.org/10.24252/mapan.2019v7n2a10

Putri. (2017). Etnomatematika, Kesenian Tradisional Rebana, Pembelajaran Matematika. Eksplorasi Etnomatematika Kesenian Rebana Sebagai Sumber Belajar Matematika Pada Jenjang Mi, IV(1), 21-31.

Rachmawati, I. (2012). Eksplorasi Etnomatematika Masyarakat Sidoarjo. MATHEdunesa, 1(1), $1-8$. 
Rahmawati Z, Y. R., \& Muchlian, M. (2019). Eksplorasi etnomatematika rumah gadang Minangkabau Sumatera Barat. Jurnal Analisa, 5(2), 123-136. https:// doi.org/10.15575/ja.v5i2.5942

Rosidah, L. (2014). Peningkatan Kecerdasan Visual Spasial Anak Usia Dini Melalui Permainan Maze. Jurnal Pendidikan Usia Dini, 8(2), 281-290.

Sumartini, S. (2018). Penerapan Permainan Pindah Kamar Dalam Menumbuh Kembangkan Kemampuan Mengenal Bentuk Geometri Pada Anak Usia Dini. Comm-Edu (Community Education Journal), 1(2), 88. https://doi.org/10.22460/commedu.v1i2.640

Syaiputra Wahyuda Meisa Diningrat, Janah, L., \& Mardiyah, S. (2019). Modified Bottle Cap for Improving Children's Arithmetic Ability. JPUD - Jurnal Pendidikan Usia Dini, 13(2), 249-263. https:/ / doi.org/10.21009/JPUD.132.04

Wahyuni, A., Aji, A., Tias, W., \& Sani, B. (2013). Peran Etnomatematika dalam Membangun Karakter Bangsa: Penguatan Peran Matematika Dan Pendidikan Matematika Untuk Indonesia Yang Lebih Baik, 1, 111-118.

Winitri, R., Hapidin, H., \& Nurani, Y. (2020). Perbedaan Hasil Belajar Matematika Anak Usia 6-7 Tahun ditinjau dari Pemahaman Guru pada Pembelajaran Transisi dan Regulasi Diri. Jurnal Obsesi: Jurnal Pendidikan Anak Usia Dini, 4(2), 491. https:// doi.org/10.31004/obsesi.v4i2.402

Zayyadi, M. (2017). Eksplorasi Etnomatematika Pada Batik Madura. ¿Igma, 2(2), 35-40. 